\title{
The Discourse of Remote Teaching During the COVID-19 Pandemic
}

\author{
Luís Cláudio Dallier Saldanha \\ Universidade Estácio de Sá
}

This paper examines the discourse of remote teaching during the COVID-19 pandemic based on its opposition to distance education. The terminological issues in this debate are identified; the main arguments of the opposition between remote teaching and distance education are addressed; and the common elements between the two educational modalities are analyzed. Based on Andrew Feenberg's Critical Theory of Technology, we argue that technological mediation in both distance and remote education has limitations as well as potentials that must be discussed.

Keywords: distance education, remote teaching, critical theory of technology

\section{INTRODUCTION}

Brazilian schools and other learning spaces offered heterogeneous responses to the challenges posed by the COVID-19 pandemic that took the world by surprise in 2020 and forced in-person classes to be suspended for months on end, as social distancing became a safety requirement.

Public and private institutions of all education levels improvised remote classes and produced a bare minimum of digital content in attempts to ensure education continuity. Virtual platforms, instant messaging apps, broadcast television and even radio were used to try and get students to keep engaging in synchronous or asynchronous pedagogical and academic activities at home.

The private sector presented faster and more thorough solutions, especially the higher education subsector. Large educational groups used their distance education experience with digital platforms and virtual content to implement alternatives when in-person classes were interrupted.

Public higher education institutions were generally more resistant to online solutions; the prevailing opinion was that remote classes could be a slippery slope to distance education, that they exacerbated preexisting social and economic disparities (given the inequality of access to the hardware and connectivity required for alternative learning solutions), and that they could result in teacher labor precarity. A small number of public higher education institutions offered remote classes on the first school semester of $2020^{1}$.

It was different in K-12 public schools: most State and municipal schools ${ }^{2}$ resorted to different actions and strategies to continue developing pedagogical activities offsite, despite numerous difficulties and limitations. A survey conducted by G1 News Agency showed that after 100 days of social distancing, 25 out of 26 Brazilian States and Distrito Federal ${ }^{3}$ had implemented remote teaching. They monitored student participation and found that many students struggled with deficient infrastructure and had trouble effectively participating in long-distance activities (Oliveira et.al., 2020).

Under these conditions, remote teaching was widely regarded as the feasible (albeit improvised) answer to the urgent challenge of continuing academic activities without face-to-face contact. The press, digital 
media and social media reverberated the discourse of certain educators and educational businesspeople who opposed remote teaching to distance education. On the other hand, many scholars critically regarded remote teaching as an equivalent to distance education or online learning, and official guidelines set by the Brazilian Ministry of Education for educational activities during and after the pandemic mentioned 'longdistance activities' and 'classes via digital media' indistinctly.

With this introduction to the Brazilian context and the terminology under discussion, we will focus on the discourse that sought to differentiate remote teaching from distance education during the pandemic. In order to understand that discourse and its possible limitations, we will identify the various terms employed to characterize or define educational activities during the pandemic, mapping their usage and contrasting them with the concept of distance education and with the recently-coined definition of remote teaching.

In addition, we will compare and contrast distance education and what has come to be referred to as 'remote teaching'. This exercise will provide the basis for our central claim: that in both cases, technological mediation raises questions, presents challenges, and opens up possibilities that must be discussed.

\section{REMOTE TEACHING AND ITS TERMINOLOGICAL VARIANTS}

'Remote Teaching' has become a common designation in some countries for the educational response to the impossibility of in-person pedagogical activities. The expression was used in specialized literature as early as March 2020, already presented in contrast with Online Learning (Hodges et.al., 2020) and also as synonymous with e-learning (Davis, 2020).

Despite being widely adopted in Brazil, 'remote teaching' was not the only expression used in reference to the alternative educational activities during the nationwide shutdown of schools and other learning spaces. The press, educational websites, official documents, and teachers also used concurrent expressions such as 'remote classes', 'emergency remote teaching', 'remote education', 'remote activities', 'remote learning', 'remote learning strategies' and 'remote classroom'.

These expressions have in common the idea of educational activities that take place in the homes of students and teachers, as conveyed by the word 'remote'. Other designations for offsite education during the pandemic highlight different aspects of these experiences, such as the use of technological resources or synchronism: 'online teaching', 'online learning', 'online education', 'online classes', 'online classroom', 'classes via digital media' and 'teleclasses'.

Aside from the plethora of expressions containing the terms 'remote' and 'online', educational activities happening outside schools and universities were also characterized as 'distance education', 'distance learning' and, in official Brazilian Ministry of Education documents, 'long-distance activities'.

As we shall see, the expression 'remote teaching' was employed almost exclusively in contrast with distance education and as a variant or equivalent of other expressions that emphasize the following aspects: spatial (remote), time (online) and technological (digital channels).

A variety of expressions were used in the press and on digital media to designate long-distance pedagogical activities. The discourse of those texts simultaneously legitimized the remote teaching solution and tried to defend distance education by arguing that it differed materially from the impromptu longdistance activities implemented during the pandemic.

However, the official documents issued in the first months of the COVID-19 pandemic use fewer expressions and are less emphatic in opposing 'remote teaching' to 'distance education': between March and October of 2020, Ministry of Education documents alternate between 'classes via digital media', which underscores the technological mediation involved, and 'long-distance activities', a broader expression that prevails in later documents.

The Ministry of Education documents do not favor the expressions 'remote classes' or 'remote teaching', and there is no noticeable effort to oppose neither long-distance activities nor classes via digital media to distance education; instead, those documents operate on a structural opposition between in-person and long-distance activities.

Although the official documents preferentially mention 'long-distance activities' and do not openly reinforce an opposition between remote teaching and distance education, the debate that took place in the 
press and on social media did engage with those questions. This calls for an analysis of the discourse on remote teaching, which we will conduct next, based on a limited set of texts.

\section{THE DISCOURSE OPPOSING REMOTE TEACHING TO DISTANCE EDUCATION}

Texts that circulated on different media justified the constant use of 'remote teaching' (RT) and 'remote classes' as the best designations for the educational activities that exceptionally took place outside traditional learning spaces, so as to set them apart from pre-pandemic, regular distance education (DE).

The cornerstone of that justification was the fact that RT is an emergency response, something unplanned, temporary, just a fast and feasible response that resorted to the Internet and digital media upon the unforeseen interruption of in-person pedagogical activities.

From this standpoint, differentiating between DE and RT would be justified by the latter's transitory nature and the subsequent lack of a pedagogical project and planning to provide the theoretical, institutional and methodological foundations for educational activities in which the participants engage in different places and moments.

According to an essay published by Daros (2020) on Portal Desafios da Educação [Education Challenges Website] in the early days of the Brazilian response to the pandemic, DE is not a proper definition or identifier for remote activities because "remote activities means using the Internet to conduct pedagogical activities in a temporary, one-time fashion, with the goal of minimizing crisis impacts on learners forced to shift from their original in-person classes.".

Daros (2020) argues that RT differs from DE on account of being an emergency, temporary solution to the interruption of ordinary pedagogical activities during the pandemic.

Four months into the pandemic, when several schools and universities had resorted to remote classes, educator Andrea Ramal was interviewed by $O$ Globo, a major Brazilian newspaper. The interview was significantly titled 'Remote teaching is not distance education', and in it Ramal stresses that schools were pushed into adapting to the new conditions imposed by pandemic with very little planning: "teachers went to bed as face-to-face professionals and woke up as online ones" (Perelló, 2020).

Ramal asserts that the educational experience outside learning spaces in times of social distancing must be regarded as RT rather than DE, because the latter "has its own methodologies, strategies and specific resources that are the result of years of studies and experience". She exemplifies her claim by saying that "most teachers began making video classes, and some schools simply assigned tasks that have nothing to do with formal distance education" (Perelló, 2020).

Ramal lists a series of DE elements that do not exist in remote classes: a) creation of a virtual community to ensure a feeling of belonging and to promote shared experiences; b) assessment of the learner's emotional experience, with the use virtual environments and tools to overcome the sensation of loneliness; c) teacher knowledge of and experience with online pedagogical practices; d) learning contents and resources produced with input from an instructional designer and designed specifically for distance learners; e) learner's discipline, autonomy and motivation to study and learn in a virtual environment (Perelló, 2020).

In conclusion, she believes that DE has didactic and pedagogical specificities and a particular student profile that set it apart from RT.

In "O ensino remoto emergencial e a educação a distância" [Emergency remote teaching and distance education], published on Rio Grande do Sul Federal University's website, scholar Patrícia Behar opposes Emergency Remote Teaching (ERT) to DE based on the following ERT features: a) geographic distance between teachers and learners; b) being a transitory emergency response; and c) a transposition of in-person teaching formats to digital media, with video classes assuming a prominent role (Behar, 2020).

After describing ERT, Behar introduces DE with a legal definition preceded by the logical connector "on the other hand", thus underscoring the opposition between DE and ERT: "On the other hand, Distance Education is education in which the didactic-pedagogical mediation of teaching and learning processes happens through information and communication technologies, with students, tutors and teachers engaging in their activities in different places and/or moments." (Behar, 2020). 
In this perspective, DE's core distinctive features would be: a) having its own practices and didacticpedagogical tenets; b) properly designed contents and activities; c) a pedagogical model built on the best interests of learners, teachers, tutors and managers, with pedagogical architecture and pedagogical strategies that promote production of knowledge on virtual environments; d) specific teaching competences related to virtual environments and distance learning; e) teachers/tutors closely follow learners' cognitive and emotional journeys (Behar, 2020)

One may reasonably conclude from Patrícia Behar's study that the major differences between RT and DE consist of how the first is an emergency response and transposes in-person classes to digital media without a pedagogical project to adequately structure that shift.

The discourse supporting the difference or opposition between RT and DE has also gained traction in social media. Amongst many messages and graphic/visual aids drawing a line between RT and DE, the following table was posted on LinkedIn, the world's largest professional social network:

\section{TABLE 1 \\ REMOTE CLASSES AND DISTANCE EDUCATION CLASSES}

\begin{tabular}{|l|l|}
\hline \multicolumn{1}{|c|}{ Remote classes } & \multicolumn{1}{c|}{ DE classes } \\
\hline $\begin{array}{l}\text { Exceptional measures to continue transmitting } \\
\text { content and meeting students through digital } \\
\text { platforms }\end{array}$ & Has its own teaching methods \\
\hline $\begin{array}{l}\text { Live or recorded classes taking place at the same } \\
\text { time scheduled for in-person educational activities }\end{array}$ & Video classes \\
\hline Resources adapted by teachers & $\begin{array}{l}\text { Standardized resources that were designed and } \\
\text { developed by a specialized team }\end{array}$ \\
\hline Interaction with the class/course teacher & Interaction with a tutor \\
\hline Use of various digital tools to present content & Use of various digital tools to present content \\
\hline Predominantly synchronous activities & Mix of synchronous and asynchronous activities \\
\hline Flexible schedule & Standardized schedule \\
\hline Adapted, course-centric evaluation & Standardized tests \\
\hline
\end{tabular}

Some of those oppositions may be up for debate or vary considerably throughout the various existing RT and DE experiences; the post also fails to mention the use of non-digital resources in RT, such as radio and broadcast television. However, the contrast between 'remote classes and DE classes' reflects the opposition between RT and DE advocated by the prevailing discourse reproduced on the websites of many a private Higher Education Institution (HEI).

Other education providers such as companies and groups that offer educational digital platforms, contents, and services have also used their communication channels and digital media to take a stance on the distinction between RT and DE, as may be gleaned from the following titles: "Lições do coronavírus: ensino remoto emergencial não é EaD" [Lessons from coronavirus: emergency remote teaching is not DE], by Grupo A (Rabello, 2020); "Conheça a diferença entre ensino remoto e EaD" [Know the difference between remote teaching and DE], by Centro Universitário UniCesumar; "Entenda as diferenças: educação remota, on-line e EaD" [Understand the differences: remote education, online education and DE], by Faz Educação \& Technologia; "Aula remota não é EaD? Entenda as diferenças e todas as vantagens" [Aren't remote classes DE? Understand the differences and advantages], posted on the IPOG - Instituto de Pós Graduação e Graduação blog; "Aulas remotas ou EaD?" [Remote classes or DE?], written by the president of the Brazilian Association of Higher Education Sponsors, originally published in a major Brazilian newspaper and later reposted on the Association's website; these are but a few examples.

Certain institutional discourses clearly opposed RT to DE using consistent and previously-defined terminology, such as "Notas técnicas 17: estratégias de aprendizagem remota (EAR), características e diferenciação da educação a distância (EAD)" [Technical notes no.17: remote learning strategies (RLS), 
features and differences from distance education (DE)], posted on the Centro de Inovação para a Educação Brasileira - CIEB website.

In its Technical Note no.17, CIEB takes a stance on the distinction between remote learning and distance education: "Remote Learning Strategies (RLS): their goal is to provide public managers the necessary information to plan and set in motion pedagogical actions in the context of social distancing. Distance Education (DE): is based on systematic work using methods and processes designed to develop learning solutions" (CIEB, 2020, p. 9).

However, as previously noted, those discourses have not always been clear and coherent in characterizing long-distance activities. Such is the case of the Technical Note "Ensino a distância na educação básica frente à pandemia da Covid-19" [Distance teaching in K-12 education as a response to the COVID-19 pandemic], by NGO Todos pela Educação. The document is structured around four points, and on a synoptic table presented in the first point 'remote teaching solutions' is used as an equivalent of 'distance education strategies'. In the synopsis of the second point, there is also an equivalence between 'remote teaching', 'long-distance solutions' and 'distance teaching'. Conversely, the document's third point states that "remote teaching is not synonymous with 'online classes" ", even while placing RT in the 'distance learning' category (Todos pela Educação, 2020).

While the document does oppose remote teaching to online classes, it still counts remote activities among the ones that fail to fully meet the educational challenge posed by the pandemic - and this list also includes distance education: "[...] remote activities, and even the more structured Distance Education (DE) ones, have limitations and cannot substitute the in-person school experience, especially on large-scale applications for primary and secondary education" (Todos pela Educação, 2020).

Despite alternating terms throughout the document and employing them somewhat ambiguously, in its final section the Technical Note clearly asserts a distinction between 'remote teaching' and 'distance education': "we have chosen to differentiate between 'Distance Education (DE)' - a teaching modality that presupposes its own organization and logic - and the expression 'remote teaching' - which underscores the mitigating nature of that solution" (Todos pela Educação, 2020).

Notably, the discourse opposing remote teaching to distance education was prevalent but not homogeneous.

In "How to transition to remote learning", a Microsoft text published in the company's Brazilian educational services website, the expression 'remote learning' is used as an equivalent of both 'distance education' and 'online learning': "As schools [...] respond to COVID-19, access to remote learning tools becomes an urgent matter. In order to facilitate the transition to distance education, we have created resources, training and instruction guides meant to help schools, educators, learners, and their families navigate remote learning" (Microsoft, 2020)

The final stage of that transition is indistinctly referred to as 'distance education' or 'remote learning', which are used synonymously.

SOMOS Educação, Brazil's largest K-12 Education Group comprising teaching systems, digital platforms, and publishing houses addresses the normative aspects of educational activities during the pandemic in "Normatização da escola digital" [Regulating the digital school]. Initially, the text names the digital school experience during the pandemic as 'distance education': "many institutions have resorted to distance education as their best bet to continue to transmit learning through a remote system during the pandemic". In section titles, however, two different expressions ('remote school activities' and 'distance teaching") are used to discuss the same question: "The regulation of remote school activities" and "The requisites that regulate distance teaching". The text clearly associates distance education to long-distance activities during the pandemic: "in order to validate distance education, the Federal Government has enacted a decree stating that current circumstances constitute an emergency and acknowledging a State of Public Calamity ${ }^{4}$. That classifies the steps taken against the coronavirus outbreak as emergency measures and thus ensures the legitimacy of those actions" (Viegas, 2020).

The short text alternates between terms and expressions to designate long-distance activities; aside from the ones already mentioned, they also use 'distance teaching', 'online activities', 'virtual modality', 'school activities conducted remotely', and 'digital modality' to discuss the activities of what they call the 'digital 
school'. This text does not oppose neither remote teaching nor digital schools to distance education, but it does employ different expressions indistinctly to cover the spectrum of pedagogical activities and experiences happening outside schools and other learning spaces in times of social distancing.

The OCDE \& Harvard Graduate School of Education e-book A framework to guide an education response to the COVID-19 Pandemic of 2020, of which an excerpt has been adapted, translated and published in Brazil by Somos Educação, acknowledges the emergence of alternate education solutions compatible with social distancing. The text is structured as a set of guidelines to support decision-making by educational leaders. Its authors advocate that teaching solutions to the educational challenges and needs caused by the pandemic should include online learning whenever possible. However, throughout the book other expressions are used to refer to education responses; in order of appearance, we have: 'online learning', 'online education', 'alternative means of delivery' (broadcast television, podcasts, radio broadcasts, learning packages in digital form or on paper), 'alternative education' and 'new modality of instruction'. Those expressions are not presented as conflicting, but rather as alternatives or complementary educational responses to the COVID-19 crisis, and the authors urge managers and leaders to "revise regulatory framework in ways that make online education and other modalities feasible" (OCDE; Harvard, 2020).

Other organizations that did not oppose RT to DE regarded the first as a damage control policy; for instance, Lemann Foundation considers long-distance activities to be unsuitable for primary and secondary students.

This section evidently does not examine the full body of texts that oppose remote teaching to distance education or use those expressions interchangeably to discuss the educational responses to the COVID-19 pandemic. However, given the intrinsic limitations of an exploratory research still on its preliminary stage, added to the fact that scholars still understand relatively little about the topic, we shall not present any further examples but rather move on to outline some implications of the aforementioned ones.

\section{CONVERGENCES BETWEEN REMOTE TEACHING AND DISTANCE EDUCATION}

The significant lack of a uniform name for the offsite pedagogical activities to which schools, universities and other learning spaces have resorted during the COVID-19 pandemic can be better understood by looking at distance education studies.

The expression 'distance education' is not exempt from terminological dispute (Cf. Moore; Kearsley, 2007, p. 4; Formiga, 2009, p. 39-46; Litto, 2010, p. 35; Mill, 2018, p. 201). Choosing descriptors or keywords to look up literature review or meta-analysis studies on that education modality is no simple task, as many relevant studies do not mention 'distance education' (Romiszowski, 2009; Saldanha, 2016).

As research on the educational experiences during the COVID-19 pandemic begins to be published, we are faced with the challenge of defining or circumscribing which expressions or descriptors best help us encompass studies on that topic and 'remote teaching' is but one among a number of options.

The matter involves more than mere terminological diversity, as the belief in a radical opposition between RT and DE often implies a problematic understanding of the latter as something homogeneous, as if there could possibly be a one-size-fits-all didactic-pedagogical DE model, or as though not a single DE course lacked planning or a consistent, modality-appropriate pedagogical model.

In favor of the opposition between DE and RT, it could be argued that on account of being an emergency measure (and as such innately suboptimal) RT has forced an improvised transposition of in-person class aspects such as duration and methodology to online or remote instructional activities, which often resulted in the so-called 'lives', video conferences or teachers resorting to simple content exposition in front of a computer or cellphone camera. However, this apparently solid opposition is not without gray areas if we consider that some DE models still rely on long classes, which are either made available asynchronously or broadcast live for students to watch in their homes or at the local study center. Thus, whilst RT and DE may not be synonymous, we must not haste into regarding them as polar opposites, with DE as a supposedly flawless long-distance education model. 
Similarly, some people even consider RT to be an improvised or low-budget form of DE, acknowledging both the differences and common aspects between them and concluding that neither are suitable for K-12 education (Zajac, 2020).

The widespread use of the expression 'remote teaching' can also be associated to DE in that the term 'remote' echoes the reference to a spatial dimension, or to distance itself, and the physical distance between teachers and students is traditionally considered one of DE's defining features, as exemplified by two classic definitions: for Cropley and Kahl (1983 apud Belonni, 2003, p. 26), DE consists in "teaching and learning processes even without any face-to-face contact between teachers and learners", and Malcolm Tight (1988 apud Belonni, 2003, p. 26) writes that "Distance education consists in organized forms of learning based on the physical distance between learners and the ones involved in the organization of that learning".

DE critics stress the pivotal role of distance in the very concept of that education modality and claim that geographically separated students and teachers must rely on virtual activities and classes, regarded as mere simulacra for in-person classes where proper instruction cannot take place: "A virtual class is just a simulacrum of an in-person class. [...] A virtual class cannot be as intense as a real class because the teacherstudent relationship is by essence an immediate one, devoid of mediation [...]" (Patto, 2013, p. 310, 313).

Even among scholars who consider DE a viable formative path, the weight of distance in theoretical formulations of that educational modality is problematic because it makes people focus on the problem (distance) instead of working towards a solution (Tori, 2010, p. 19).

In contrast, rather than concentrate on geographical distance (which tends to reduce DE to an aspect that should not play such a defining role) DE researchers present the concept of transactional distance: overcoming space, psychological and communication gaps using technology to achieve interaction, dialogue and pedagogical mediation (Moore, 2002).

Technological mediation enables teachers and students to be virtually together and to interact across space and time, and it is a component of both remote teaching and distance education. Throughout the coronavirus pandemic, RT actually ended up using a number of resources historically employed in DE: virtual platforms, digital applications, video classes, broadcast television, radio broadcasts and even paperbased learning packets.

The emergency context, subsequent or pre-existing infrastructure and communication limitations, and the fact that thousands of students did not have Internet access in their homes, compounded with other social and economical issues, pushed RT to develop both analogical and digital solutions.

This is an excellent reminder that even though digital information and communication technologies (commonly called "new technologies") tend to prevail both in DE and RT solutions, they are not requisite for educational technological mediation. Other devices and technological processes involving print, radio and television also have a history of DE application.

Contrary to popular belief, the presence of technology in schools is not limited to communication and information devices: "[...] some educators associate the word 'technology' exclusively to computers in the classroom, but the school building, and some of a teacher's oldest aids, such as the blackboard, can be considered technology in a broader sense of the term" (Dusek, 2009, p. 44).

Therefore, it can be productive to avoid too narrow a definition of technology such as the "current trend of using 'technology' exclusively in reference to computers and cellphones, leaving out machines and other technological artifacts" (Dusek, 2009, p. 46).

However, simply acknowledging that the radio and paper-based resources also constitute technological solutions to continue pedagogical activities during the pandemic does nothing to mitigate the technological limitations and the digital divide that forced several schools (predominantly those in rural areas and/or lowincome neighborhoods) to resort to outdated educational technologies.

As students' infrastructure and connectivity limitations required public schools to rely on analogical technologies, pre-existing disparities between public and private schools are further exacerbated and become even more glaring. The pandemic has aggravated the insidious, historical, and structural digital exclusion of thousands of Brazilian students. 
Amongst other relevant similarities between RT and DE when it comes to technological mediation and the central role of technology in pedagogical mediation, the next section will briefly address how technology is not a neutral element, especially in education.

\section{AN ARGUMENT AGAINST THE IDEA OF NEUTRAL TECHNOLOGY}

While the instrumentalist approach regards technology as a tool that can only be considered good or bad depending on how it is used (the means are independent from the ends = neutrality), a critical theoretical approach acknowledges that technology is not neutral

Andrew Feenberg's (2015) Critical Theory of Technology holds that rather than being a mere tool at our disposal, technology realizes a project that permeates every sphere of human life and shapes our environment according to certain sets of values.

The social significance of technology far surpasses its functionality and the goal of efficiency inherent to every technological project: "[...] technology is an integral part of a certain way of life and it encompasses not only the bare minimum significance directly related to its function, but also a wide array of connotations that connect it to many aspects of the human world it is involved in" (Feenberg, 2015, p. 210).

Feenberg cites the example of how computers "transform intellectual property regimes, change the relationship between individual expression and mass communication, overcome several types of social isolation and so on." (Feenberg, 2015, p. 185).

In the same vein, we could look at how digital platforms and contents widely used in RT and DE are not exempt from a) the software industry; b) the commercial interests of service providers; c) a massification of teaching; d) the technical limitations of some functionalities that could improve interactivity; e) a layout or design biased by certain learning conceptions (often reduced to instructionist or behaviorist approaches); f) the splitting of teacher activities between various professionals (authors, writers, script writers, video classes presenters, cameramen, instructional designers, web designers, tutors, etc.); and g) the intensification of teaching labor - not to mention other potentially problematic aspects that could pose obstacles to an emancipatory and integral pedagogical project. Nonetheless, virtual learning environments can also allow us to technologically overcome physical distance; to produce virtual presence; to foster collaborative communities; to facilitate information access; to use a mix of various languages and media as means of favoring expressive communication and offering content presentation alternatives; to develop innovative technological operations that can help us reach truly significant educational goals, among other possibilities.

As an example, let us look at the technological functionality that allows students and teachers to see each other and to interact during live remote classes.

Even as we remain duly critical of mere transpositions of the culture of in-person classes to virtual ones, with lengthy expositions performed by a teacher and scarce participation of other class members, we still believe that it is possible to have dialogic and interactive experiences in remote classes if they rely on proper didactic-pedagogical planning and perform critical and creative appropriations of technology. The microphone and camera icons pervasive in remote pedagogical activities could be turned into possibilities of student-teacher and student-student dialogue and interaction. However, during the pandemic what we saw was a parade of 'memes' and other social commentary on how the muted microphones and disabled camera icons symbolized students' de facto absence from remote classes, even as they were nominally in attendance. The very same functionality that represents the possibility of dialogue ended up representing the invisibility and silence of many students; therefore, whilst technology does enable connectivity, it cannot guarantee quality of presence and inter-subjective contact.

Aside from the various technological possibilities inscribed in any technological project, we cannot overlook the fact that technology can be reinterpreted, that new functions may be introduced and shifts in functionality can occur as the meaning of technology changes. However, transforming technology to better serve educational ends is a complex task that begins by interpreting technology in education - in any educational modality - and must go beyond the sphere of education, tackling society and power structures. 
Technology would have to be at the service of a sensitive environment, the work world would have to become a world of actual human relations, and productivity would need to be converted into creativity; all of this could be achieved by perfecting technology towards an object world where we strove for harmony between human beings and our world (Marcuse, 2001).

\section{CONCLUSION}

Over the course of this study, we have sought to demonstrate that although different terms were used to designate the education solution to the impossibility of in-person pedagogical activities during the COVID-19 pandemic, distinguishing or even opposing remote teaching to distance education cannot minimize nor erase their many common challenges and limitations.

In any education project, technological choices must consider not only the use or application of technological resources in face-to-face or long-distance pedagogical activities, but also how technology is imbued with social meanings and values that must be acknowledged if technology is to truly serve educational ends.

Along with key educational elements such as consistent planning, emancipatory pedagogic projects, and dialogic didactic practices, it is essential that we come to regard technology critically rather than viewing it as a mere educational tool whose capacity for doing good depends solely on its use by a human actor.

Regardless of whether one chooses the discourse of resistance, concession or acceptance of remote teaching or distance education, questioning the place and value of technology is of the utmost importance.

\section{ENDNOTES}

1. The Brazilian school year starts in February and ends in December, with 30 days off between semesters in July.

2. In Brazil, municipalities are responsible for elementary and middle schools while States operate high schools.

3. The Brazilian capital is its own administrative unit, on par with states.

4. In Brazilian law, a State of Public Calamity is similar to the USA concept of State of Emergency in which exceptional policies are adopted in the name of citizen safety and protection.

\section{REFERENCES}

Behar, P.A. (2020, July). O ensino remoto emergencial e a educação a distância [Emergency remote teaching and distance education]. Retrieved from https://www.ufrgs.br/coronavirus/base/artigo-oensino-remoto-emergencial-e-a-educacao-a-distancia/

Belloni, M.L. (2003). Educação a distância [Distance education]. Campinas, SP: Autores Associados.

CIEB. (2020). Notas técnicas \#17: Estratégias de aprendizagem remota (EAR), características e diferenciação da educação a distância (EAD) [Technical notes no.17: Remote learning strategies (RLS), features and differences from distance education (DE)]. São Paulo, SP: CIEB.

Daros, T. (2020, March). Covid-19 impulsiona uso de metodologias ativas no ensino a distância [COVID-19 bolsters use of active methodologies in distance learning]. Retrieved from https://desafiosdaeducacao.grupoa.com.br/coronavirus-metodologias-ativas/

Davis, E. (2020, August). What is remote teaching. Retrieved from https://tophat.com/glossary/r/remoteteaching/

Feenberg, A. (2015). Tecnologia, modernidade e democracia [Technology, modernity and democracy]. Lisboa, LX: MIT Portugal, In+ Inovatec.

Formiga, M. (2009). A terminologia da EaD [DE terminology]. In F. Litto \& M. Formiga (Orgs.), Educação a distância: O estado da arte (pp. 39-46). São Paulo, SP: ABED, Pearson.

Hodges, C., Moore, S., Lockee, B., Trust, T., \& Bond, A. (2020, March). The difference between emergency remote teaching and online learning. Educause Review. Retrieved from 
https://er.educause.edu/articles/2020/3/the-difference-between-emergency-remote-teaching-andonline-learning

Litto, F.M. (2010). Aprendizagem a distância [Distance learning]. São Paulo, SP: Imprensa Oficial do Estado de São Paulo.

Marcuse, H. (2001). Toward a critical theory of society. Nova York, NY: Routledge. (Collected Papers, vol. 2).

Mattar, J. (2020, June). O que estamos aprendendo sobre educação a distância durante a pandemia do Covid-19? [What are we learning about distance education during the COVID-19 pandemic?]

Blog Ensinar a Distância. Retrieved from https://eagoraead.wixsite.com/ensinaradistancia/post/oque-estamos-aprendendo-sobre-educa $\% \mathrm{C} 3 \% \mathrm{~A} 7 \% \mathrm{C} 3 \% \mathrm{~A} 3 \mathrm{o}-\mathrm{a}-\mathrm{dist} \% \mathrm{C} 3 \% \mathrm{~A} 2$ ncia-durante-apandemia-do-covid-19.

Microsoft. (2020). Como fazer a transição para a aprendizagem remota [How to transition to remote learning]. Retrieved from https://www.microsoft.com/pt-br/education/remote-learning .

Mill, D. (2018). Educação a distância [Distance education] In D. Mill (Org.), Dicionário crítico de educação e tecnologias e de educação a distância. Campinas, SP: Papirus.

Moore, M.G. (2002, August). Teoria da distância transacional [Theory of transactional distance]. Revista Brasileira de Aprendizagem Aberta e a Distância. Retrieved from http://www.abed.org.br/revistacientifica/Revista_PDF_Doc/2002_Teoria_Distancia_Transacional Michael_Moore.pdf

Moore, M.G., \& Kearsley, G. (2007). Educação a distância: uma visão integrada [Distance education: A Systems View of Online Learning]. São Paulo, SP: Cengage Learning.

OCDE; Harvard. (2020). Resposta educacional à pandemia do COVID-19 [An education response to the COVID-19 pandemic]. São Paulo, SP: Somos Educação.

Oliveira, E., Donadoni, M., Vieira, B., Borges, B., Caetano, L., Martins, V., . . Santana, V. (2020, July). $60 \%$ dos estados monitoram acesso ao ensino remoto: resultados mostram 'apagão' do ensino público na pandemia $[60 \%$ of states monitor remote teaching access: Results show public school 'blackout' during the pandemic] G1. Retrieved from https://g1.globo.com/educacao/noticia/2020/07/06/60percent-dos-estados-monitoram-acesso-aoensino-remoto-resultados-mostram-apagao-do-ensino-publico-na-pandemia.ghtml

Patto, M.H.S. (2013). O ensino a distância e a falência da educação [Distance teaching and the demise of education]. Educ. Pesqu., 39(2), 303-318. Retrieved from https://www.scielo.br/pdf/ep/v39n2/a02v39n2.pdf

Perelló, D. (2020, June 6). Ensino remoto não é educação a distância [Remote teaching is not distance education]. O Globo. Rio de Janeiro, RJ. Retrieved from

https://oglobo.globo.com/rio/bairros/ensino-remoto-nao-ensino-distancia-diz-especialista-emeducacao-1-24501996

Rabello, M.E. (2020, Abril). Lições do coronavírus: ensino remoto emergencial não é EaD [Lessons from coronavirus: Emergency remote teaching is not DE] Desafios da Educação. Retrieved from https://desafiosdaeducacao.grupoa.com.br/coronavirus-ensino-remoto/

Romiszowski, A.J. (2009). Aspectos da pesquisa em EaD [DE research aspects]. In F. Litto \& M. Formiga, Educação a distância: $O$ estado da arte (pp. 422-434). São Paulo, SP: ABED, Pearson.

Saldanha, L.C. (2016). Meta-análise da pesquisa em educação a distância [A meta-analysis of distance education research]. Arte Factum Revista de Estudos em Linguagem e Tecnologia, VII(1), 1-14.

Retrieved from http://artefactum.rafrom.com.br/index.php/artefactum/article/view/965

Todos pela Educação. (2020, April). Nota técnica: ensino a distância na educação básica frente à pandemia da covid-19 [Technical note: Distance teaching in K-12 education as a response to the COVID-19 pandemic]. Retrieved from

https://www.todospelaeducacao.org.br/_uploads/_posts/425.pdf?1730332266=\&utm_source=cont eudo-nota\&utm_medium=hiperlink-download 
Tori, R. (2010). Educação sem distância: as tecnologias interativas na redução de distâncias em ensino e aprendizagem [Educating without distance: The role of interactive technologies in reducing teaching and learning distances]. São Paulo, SP: SENAC.

Viegas, A. (2020, June). Normatização da escola digital [Regulating the digital school] Blog Tecnologia da educação, Somos Par. Retrieved from https://www.somospar.com.br/normatizacao-da-escoladigital/ .

Zajac, D. (2020, August). Ensino remoto na Educação Básica e COVID-19: um agravo ao Direito à Educação e outros impasses [Remote teaching in K-12 education and COVID-19: An affront to the Right to Education and other dilemmas] EPUFABC. Retrieved from

http://proec.ufabc.edu.br/epufabc/ensino-remoto-na-educacao-basica/ 